\title{
Longitudinal data analysis of polymorphisms in the K-casein and $\beta$-lactoglobulin genes shows differential effects along the trajectory of the lactation curve in tropical dairy goats
}

\author{
Samir Julián Calvo Cardona, ${ }^{*}$ Henry Cardona Cadavid, ${ }^{*}$ Juan David Corrales, $† \ddagger$ Sebastián Munilla,ł \\ Rodolfo J. C. Cantet, $\$ \S$ and Andrés Rogberg-Muñoz $\#^{1}$ \\ *Grupo de Investigación en Genética, Mejoramiento y Modelación Animal (GaMMA), Facultad Ciencias Agrarias, Universidad de Antioquia, \\ Calle 67, no 53-108, AA 1226, Medellín, Colombia 005043 \\ †Facultad Ciencias Agropecuarias, Universidad de La Salle, Bogotá, Colombia 110231 \\ ‡Departamento de Producción, Facultad de Agronomía, Universidad de Buenos Aires, San Martín 4453 (1417), \\ Ciudad Autónoma de Buenos Aires, Argentina \\ §Unidad Ejecutora de Investigaciones en Producción Animal (INPA), Universidad de Buenos Aires - Consejo Nacional de Investigaciones \\ Científicas y Técnicas, Cdad. Atma. Buenos Aires (1417), Argentina \\ \#IGEVET-Instituto de Genética Veterinaria "Ing. Fernando Noel Dulout" (UNLP - CONICET La Plata), Facultad de Ciencias Veterinarias, \\ Universidad Nacional de La Plata, Calle 60 y 118 S/N, La Plata, Argentina 1900
}

\section{ABSTRACT}

The $\kappa$-casein $(C S N-3)$ and $\beta$-lactoglobulin $(B L G)$ genes are extensively polymorphic in ruminants. Several association studies have estimated the effects of polymorphisms in these genes on milk yield, milk composition, and cheese-manufacturing properties. Usually, these results are based on production integrated over the lactation curve or on cross-sectional studies at specific days in milk (DIM). However, as differential expression of milk protein genes occurs over lactation, the effect of the polymorphisms may change over time. In this study, we fitted a mixed-effects regression model to test-day records of milk yield and milk quality traits (fat, protein, and total solids yields) from Colombian tropical dairy goats. We used the well-characterized $A / B$ polymorphisms in the $C S N-3$ and $B L G$ genes. We argued that this approach provided more efficient estimators than cross-sectional designs, given the same number and pattern of observations, and allowed exclusion of between-subject variation from model error. The $B L G$ genotype $A A$ showed a greater performance than the $B B$ genotype for all traits along the whole lactation curve, whereas the heterozygote showed an intermediate performance. We observed no such constant pattern for the $C S N-3$ gene between the $A A$ homozygote and the heterozygote (the $B B$ genotype was absent from the sample). The differences among the genotypic effects of the $B L G$ and the $C S N-3$ polymorphisms were statistically significant during peak and mid lactation

\footnotetext{
Received January 27, 2016.

Accepted June 7, 2016.

${ }^{1}$ Corresponding author: arogberg@agro.uba.ar
}

(around 40-160 DIM) for the $B L G$ gene and only for mid lactation (80-145 DIM) for the $C S N-3$ gene. We also estimated the additive and dominant effects of the $B L G$ locus. The locus showed a statistically significant additive behavior along the whole lactation trajectory for all quality traits, whereas for milk yield the effect was not significant at later stages. In turn, we detected a statistically significant dominance effect only for fat yield in the early and peak stages of lactation (at about 1-45 DIM). The longitudinal analysis of test-day records allowed us to estimate the differential effects of polymorphisms along the lactation curve, pointing toward stages that could be affected by the gene.

Key words: longitudinal data, dairy goats, additive, dominance, $\beta$-lactoglobulin, $\kappa$-casein

\section{INTRODUCTION}

Most of the proteins contained in the milk of domestic ruminants (goats, sheep, and cattle) are encoded by 6 well-characterized genes: $L A L A B, B L G, C S N 1 S 1$, CSN1S2, CSN2, and CSN3 ( $\alpha-\mathrm{LA} ; \beta-\mathrm{LG}$; and $\alpha_{\mathrm{S1}^{-}}, \alpha_{\mathrm{S}_{2}}$, $\beta$-, and $\kappa$-caseins; Kumar et al., 2006). Several studies on $\kappa$-casein $(C S N$-3) and $\beta$-lactoglobulin $(B L G)$ genes in cattle, goats, and sheep have identified polymorphisms with allelic and genotypic effects on milk yield, milk composition, and cheese-manufacturing properties (Moioli et al., 1998; Martin et al., 2002; Boettcher et al., 2004; Caroli et al., 2009; Caravaca et al., 2011). In particular, association studies in goats based on polymorphisms on the $C S N$-3 and $B L G$ genes showed genetic effects on milk yield and milk quality traits (Kumar et al., 2006; Caravaca et al., 2011; Dagnachew et al., 2011). 
The casein genes are located on caprine chromosome 6 (CHI6), whereas $\alpha$-LA and $\beta$-LG genes have been mapped to caprine chromosomes 5 and 11 , respectively (Martin et al., 2002). Sequencing of the $C S N$-3 gene has revealed a high level of diversity at both the DNA and protein levels, and several variants have been described (Caroli et al., 2001; Yahyaoui et al., 2003; Prinzenberg et al., 2005). The $A / B$ group differentiation is related to a transition from $\mathrm{A}$ to $\mathrm{G}$ on exon IV (CHR6 position 82,906,117 CHIR_1.0 assembly) that produces the amino acid substitution D111G (Yahyaoui et al., 2003; Kumar et al., 2009). Association studies of this polymorphism with milk production showed diverse results for the effect of each allele (Caravaca et al., 2009; Vacca et al., 2014). The $B L G$ gene is also extensively polymorphic, and a great number of genetic variants have been reported in the promoter, coding, and noncoding regions (Ballester et al., 2005; Sardina et al., 2012). Among them, the SacII polymorphism at exon VII (rs666423193, A > G) defines the A and B genotypes. Association studies based on this polymorphism have detected a positive effect of the A allele in milk production in goats (Kumar et al., 2006; El Hanafy et al., 2015).

Differential expression of milk protein genes has been reported throughout lactation in dairy animals (Bionaz and Loor, 2007; Berget et al., 2010). This suggests that the effect of polymorphisms in these genes on milk yield and milk quality traits may change along the lactation curve. In general, the time-dependent effects of genes during lactation have been studied in dairy animals (Strucken et al., 2012a,b). In particular, different statistical approaches have been invoked to test the effect of candidate SNP along the lactation curve for different traits in dairy species, such as mixed-effects models (Pauciullo et al., 2012) or random regression models with Legendre polynomials (Banos et al., 2008; Banos and Coffey, 2010; Szyda et al., 2014). In this study, we fitted a mixed-effects regression model for longitudinal data following the approach of Rogberg-Muñoz et al. (2013). According to Hedeker and Gibbons (2006), this kind of longitudinal analysis provides more efficient estimators than cross-sectional designs, given the same number and pattern of observations, and allows for exclusion of between-subject variation from errors. Specifically, the goal of this research was to estimate the genotypic effects of polymorphisms in the CSN-3 and $B L G$ genes on milk yield and milk quality along the lactation curve using data from Colombian tropical dairy goats. Based on these results, we also estimated the additive and dominance effects of the $B L G$ locus as a function of DIM.

\section{MATERIALS AND METHODS}

\section{Animals and Phenotypic Data}

The study population comprised 281 dairy goats from 12 herds in the Department of Antioquia, Colombia, expanding a genealogy of 406 individuals (see details about pedigree completeness and number of lactations in Supplementary Tables S1 and S2; http:// dx.doi.org/10.3168/jds.2016-10954). Animals were bred with ad libitum access to cultivated grass (Cynodon nlemfuencis, Pennisetum spp., Pennisetum purpureum) and native arboreal species (Morus alba, Tithonia diversifolia, Trichantera gigantea, Boehmeria nivea). We collected test-day records $(\mathrm{n}=4,278)$ between January 2007 and October 2011. Each record included milk yield, fat yield, protein yield, and TS yield (all in grams). The average length of lactation was $210 \mathrm{~d}$, and information on herd, breed (phenotypically assigned), and number of births was also recorded as described by Calvo Cardona et al. (2015). Lactations with fewer than 3 test-day records were excluded from the analysis.

\section{Samples and Genotyping}

Blood samples were collected from the jugular vein using an evacuated tube containing EDTA as anticoagulant. We extracted DNA from samples using the salting out method described by Miller et al. (1988). Two SNP were genotyped, 1 located in exon IV of the $\kappa$-casein gene $(C S N-3)$ and 1 located in exon VII of the $\beta$-lactoglobulin gene $(B L G)$. Genotypes were assessed by PCR-RFLP as described in Kumar et al. (2006) and Kumar et al. (2009), using HaeIII and SacII restriction enzymes, respectively. We also genotyped 10 microsatellites to evaluate the genetic structure of the sampled goats. The genotyped markers were BM1329, BM1818, BM6526, CSSM31, ETH10, ETH225, ILSTS011, ILSTS005, INRA64, and MAF065, as described by Calvo et al. (2012).

\section{Genetic Structure}

The Structure 2.3.4 (Pritchard et al., 2000) software was executed to cluster the animals into genetic groups. The sampled population was known to derive from bucks of 3 imported breeds (Alpine, Saanen, and Toggenburg) mated to Creole does. Considering this scenario, we used the "admixed model" with correlated frequencies and the sampling location and breed information options. Each cluster analysis was performed 5 times, with a burn-in period of 10,000 cycles followed 
by 100,000 iterations. The number of distinct clusters $(K)$ considered was $2,3,4$, and 5.

\section{Statistical Model}

We analyzed each trait independently by fitting a mixed-effects regression model for longitudinal data (Hedeker and Gibbons, 2006). The fixed part of the model comprised time-independent classificatory effects of herd and parity, and an average phenotypic trajectory for each genotype. We assessed several alternative formulations, such as nesting the herd effect in the altitude of the herd or nesting the trajectory in the lactation number, by means of the Bayesian information criterion. Importantly, because the genetic structure analysis showed that the goats clustered better by herd than by breed, we did not include the latter effect in the statistical model (see Results). We let

$$
y_{i j k: t}=\mathbf{x}_{i}^{\mathrm{T}} \boldsymbol{\beta}+g(t)_{j}+r(\delta, t)_{i}+e_{i j k: t},
$$

where $y_{i j k: t}$ represents the $k$ th record of individual $i$ with genotype $j$ at time $t$ (DIM), $\boldsymbol{\beta}$ is a parameter vector for the time-independent fixed effects of herd (12 levels) and parity ( 7 levels), and $\mathbf{x}_{i}$ is the corresponding incidence vector for the $i$ th individual. The function $g(t)_{j}$ accounted for the average phenotypic trajectory of all animals with the $j$ th genotype for either $C S N-3$ or $B L G$ (2 and 3 levels, respectively), and was defined by the following quadratic polynomial:

$$
g(t)_{j}=\alpha_{0 j}+t \alpha_{1 j}+t^{2} \alpha_{2 j}
$$

where $\alpha_{0 j}, \alpha_{1 j}$, and $\alpha_{2 j}$ denote the independent, linear, and quadratic coefficients for DIM $(t)$ associated with the $j$ th genotype.

In turn, $r(\delta, t)_{i}$ represents a quadratic random regression function defined by

$$
r(\delta, t)_{i}=t \delta_{1 i}+t^{2} \delta_{2 i}
$$

where $\delta_{1 i}$ and $\delta_{2 i}$ denote the linear and quadratic random coefficients for DIM $(t)$ associated with the $i$ th animal. This function modeled the individual's deviations around the average phenotypic trajectory. Because it was specified as random, we assumed the following covariance structure:

$$
\left[\begin{array}{cc}
\operatorname{Var}\left(\delta_{1 i}\right) & \operatorname{Cov}\left(\delta_{1 i}, \delta_{2 i}\right) \\
\operatorname{Cov}\left(\delta_{2 i}, \delta_{1 i}\right) & \operatorname{Var}\left(\delta_{2 i}\right)
\end{array}\right] \otimes \mathbf{A},
$$

where $\mathbf{A}$ is the additive relationship matrix (of order $406 \times 406)$ and $\otimes$ is the Kronecker operator.

Finally, $e_{i j k: t}$ stands for an independent normally distributed error.

\section{Data Analysis}

We fitted the model using SAS version 9.3, SAS Institute Inc., Cary, NC. We computed matrix A using the INBREED procedure, and estimated the covariance components by REML using the MIXED procedure. We estimated differences between genotypes for each trait along the lactation curves using linear contrasts. Point estimates were tested every $5 \mathrm{~d}$, from 1 to 210 DIM, to define intervals with significant differences among genotypes. In addition, we estimated additive and dominance effects for each point in the lactation curve. Following Falconer and Mackay (1996), the additive effect $(a)$ is half the difference between the homozygous genotypes, whereas the dominance effect $(d)$ is the difference between the heterozygous genotype and the homozygous average. In terms of the statistical model, the estimators for time $t$ were

$$
\hat{a}_{t}=\frac{\hat{g}(t)_{A A}-\hat{g}(t)_{B B}}{2}
$$

and

$$
\hat{d}_{t}=\hat{g}(t)_{A B}-\frac{\hat{g}(t)_{A A}+\hat{g}(t)_{B B}}{2} .
$$

The $\alpha$-level of significance for contrasts and genetic effects was set to 0.01 , and degrees of freedom were corrected using the method from Kenward and Roger (1997).

\section{RESULTS}

Table 1 summarizes the number of individuals, the observed and expected genotypic frequencies, (obtained either by direct counting or under the assumption of Hardy-Weinberg equilibrium), and the phenotypic records available for each genotype. For $C S N-3 \mathrm{SNP}$, no $B B$ genotypes were observed in the population sampled. Under Hardy-Weinberg equilibrium, the expected frequency of the $B B$ genotype given the observed allelic frequencies would be $f(B B)=f(B)^{2}=(1 / 2 \times 0.23)^{2}=$ 0.0132 . In this scenario, a rough calculation based on binomial distribution indicated that the probability of not retrieving a $B B$ genotype in a sample of 245 individuals would be $3.8 \%$. Although this calculation as- 
Table 1. Summary of genotypic and phenotypic data available for $\beta$-lactoglobulin $(B L G)$ and $\kappa$-casein $(C S N$-3)

\begin{tabular}{|c|c|c|c|c|c|c|c|c|}
\hline \multirow[b]{2}{*}{ Gene } & \multirow[b]{2}{*}{$\begin{array}{l}\text { SNP } \\
\text { genotype }\end{array}$} & \multirow[b]{2}{*}{$\begin{array}{c}\text { No. of } \\
\text { individuals }\end{array}$} & \multirow[b]{2}{*}{$\begin{array}{l}\text { Observed } \\
\text { frequency }\end{array}$} & \multirow[b]{2}{*}{$\begin{array}{c}\text { Expected } \\
\text { frequency } \\
\text { under HWE }{ }^{1}\end{array}$} & \multicolumn{4}{|c|}{ No. of test-day records } \\
\hline & & & & & $\begin{array}{l}\text { Milk } \\
\text { yield }\end{array}$ & $\begin{array}{l}\text { Protein } \\
\text { yield }\end{array}$ & $\begin{array}{l}\text { Fat } \\
\text { yield }\end{array}$ & $\begin{array}{c}\mathrm{TS} \\
\text { yield }\end{array}$ \\
\hline \multirow{2}{*}{$B L G$} & $A B$ & 149 & 0.530 & 0.455 & 2,338 & 2,043 & 2,044 & 2,044 \\
\hline & $B B$ & 24 & 0.086 & 0.123 & 403 & 361 & 361 & 361 \\
\hline$C S N-3$ & $A A$ & 188 & 0.767 & 0.781 & 2,837 & 2,435 & 2,436 & 2,436 \\
\hline
\end{tabular}

${ }^{1} \mathrm{HWE}=$ Hardy-Weinberg equilibrium. Expected genotypic frequencies were computed based on observed allelic frequencies.

sumes that the population has been randomly sampled, which was not exactly true, the result suggests that the population could have been selected against the $B B$ genotype.

The cluster analysis performed to test the genetic structure of the population showed an admixed origin of almost all herds, with an optimal number of clusters of 3 (Supplementary Figure S1; http://dx.doi. org/10.3168/jds.2016-10954). This was in agreement with the history of this goat population, originally formed by mating imported bucks (from Alpine, Saanen, and Toggenburg breeds) to Creole does. Although the individuals were phenotypically classified into breed groups (Calvo Cardona et al., 2015), the genetic clustering showed that no real breed structure was present in the data. Instead, the clustering assignment evidenced a genetic structure that could be better explained by the herd of origin (Supplementary Figure S2; http:// dx.doi.org/10.3168/jds.2016-10954). When grouping the animals by herd, individuals belonging to the same herd showed a common proportion of each cluster, and this pattern was unique among herds. Findings were not the same when the animals were grouped by breed (Supplementary Figure S2).

For every trait assayed, the chosen model fit the data well. The fixed effects of herd and parity, as well as the fixed coefficients related to the average phenotypic trajectory, are presented in Supplementary Table S3 (http://dx.doi.org/10.3168/jds.2016-10954) and were always statistically significant $(P<0.05)$. Parity level estimates were as expected for all traits, with larger productions between the third and fifth lactation, except for estimates of the seventh parity. In this latter case, estimates were larger than expected but also with a larger standard error, probably due to the smaller number of observations. For the herd effect, the estimates reflected great differences in management and environmental conditions on each farm. It is worth mentioning that we also tested altitude as a separate fixed effect, nesting herd within altitude, but the fit did not improve of the Bayesian information criterion. As well, the herd effect accounted for variance among altitudes. In any case, the altitude at which each herd was located is presented in Supplementary Table S3.

Genotype LSM for both loci at specific DIM along the lactation curve $(t=15,60,105,150$, and 210) are presented in Table 2. We chose these times because they approximately represented the thresholds of the different stages of lactation, labeled "early," "peak," "mid," and "late," taken from the paper by Calvo Cardona et al. (2015). Overall, $B L G$ genotype $A A$ showed a greater performance than $B B$ for all traits along the whole lactation curve. The heterozygote, in turn, showed an intermediate performance. We observed no such constant pattern between the $A A$ homozygote and the heterozygote for the $C S N$-3 gene. Figure 1 displays the estimated trajectories.

Differences among $B L G$ and $C S N$-3 genotypes for milk yield and milk quality traits (fat, protein, and TS yields) were not constant along the lactation curve. Table 3 displays the time intervals (in DIM) where the contrasts between paired genotypes were statistically significant $(P<0.01)$. In the case of the $B L G$ gene, we estimated significant differences between both homozygotes for all traits from the time around peak lactation peak and mid-lactation. We observed no significant differences between the $A A$ genotype and the heterozygote $A B$, but the contrasts of $B B$ and $A B$ showed different patterns among traits, ranging from differences around the peak for protein yield to differences along the whole lactation for fat yield. In the case of the $C S N$-3 gene, we estimated significant differences only for fat yield and TS yield between the $A A$ genotype and the heterozygote at mid lactation.

Table 4 displays lactation time intervals showing statistically significant additive and dominance effects for the $B L G$ locus. These effects could not be estimated for the CSN-3 locus because 1 of the genotypes was absent from the sample. We estimated an additive effect along the whole lactation trajectory for all quality 


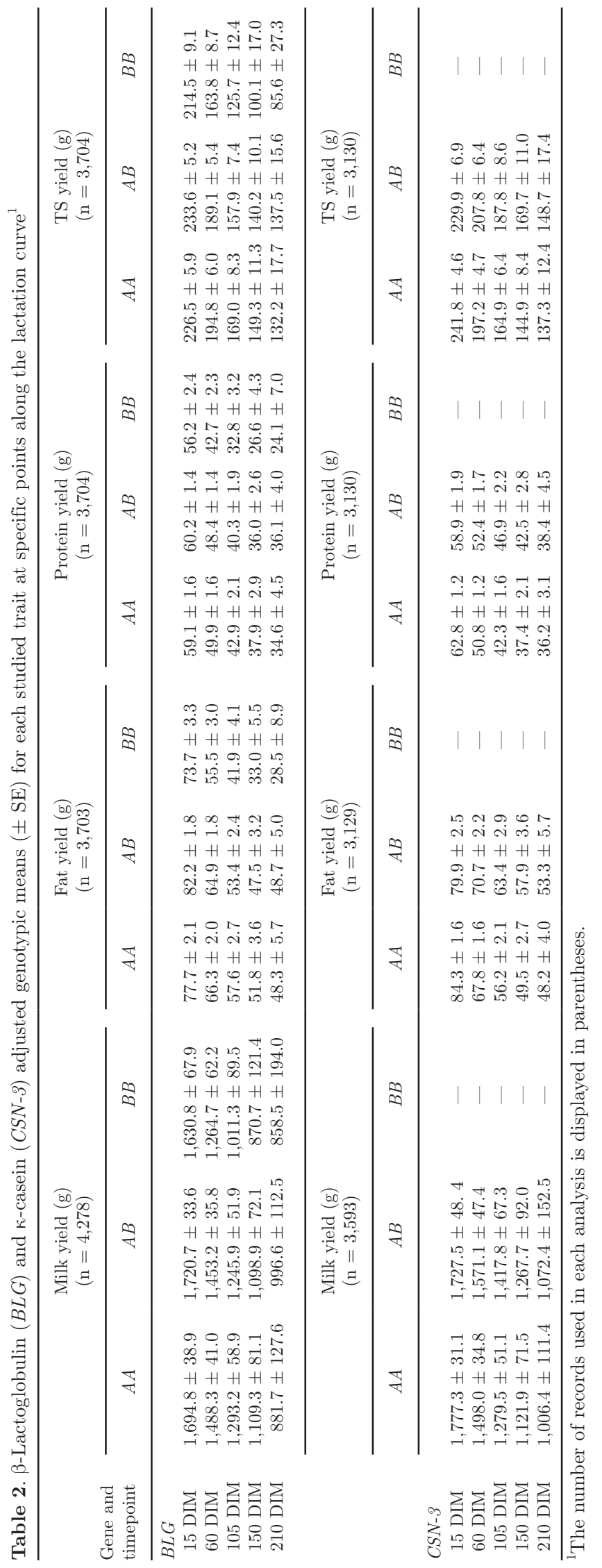

traits, although the effect for milk yield was not significant at later stages. As expected, this pattern followed closely the intervals where the differences between homozygotes were important. In contrast, we estimated a significant dominance effect only for fat yield at early stages of the lactation curve.

\section{DISCUSSION}

Several studies that examined the association between polymorphisms in the $B L G$ and $C S N-3$ genes with milk yield and milk quality traits in dairy animals have reported effects on the adjusted total production (Kučerová et al., 2006; Kumar et al., 2006; Berget et al., 2010; Dagnachew et al., 2011). In this study, we took a step forward by estimating the genotypic effects of the polymorphisms along the lactation curve using test-day records from tropical dairy goats previously analyzed by Calvo Cardona et al. (2015). In that study, the authors first chose a mathematical function for the lactation curve and then modeled each parameter of the selected curve using a fixed effects linear model. In this study, we directly fitted the performance data using a mixed-effects longitudinal model. This allowed us to test the genetic effects of the polymorphisms in the $\kappa$-casein and $\beta$-lactoglobulin genes along the lactation curve day by day. More precisely, the statistical model we employed combined a fixed average trajectory for each trait, nested within the available genotypes for each gene, with individual random deviations around it, similar to a random regression model (Schaeffer, 2004). Given a known genealogy, the approach allowed us to adjust for correlations among records of related individuals, diminishing the error variance. The timedependent function used to model the lactation curve was quadratic. Although we also tested higher-order polynomials, the quadratic function led to the most parsimonious model as assessed by the Bayesian information criterion.

Longitudinal studies point to which stages of the curve can be affected by the gene, independent of knowing where the genes exert their activity in the body (Strucken et al., 2012a). Those authors demonstrated that the effect of a particular region of the genome over a trait along lactation differed from the productive trajectory and was particular for each region/trait analysis. This finding results in a pattern of gene effects over traits for each stage, but the authors also found differences between parities. Our results indicated that the effects of polymorphisms of the $B L G$ and $C S N-3$ genes on milk yield and milk quality traits were not constant along the lactation curve.

In goats, Shi et al. (2015) have demonstrated that the expression of $B L G$ increased during lactation but 


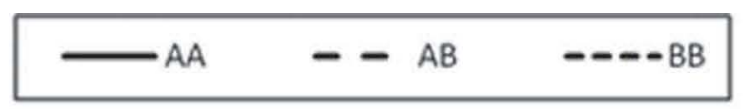

(a)
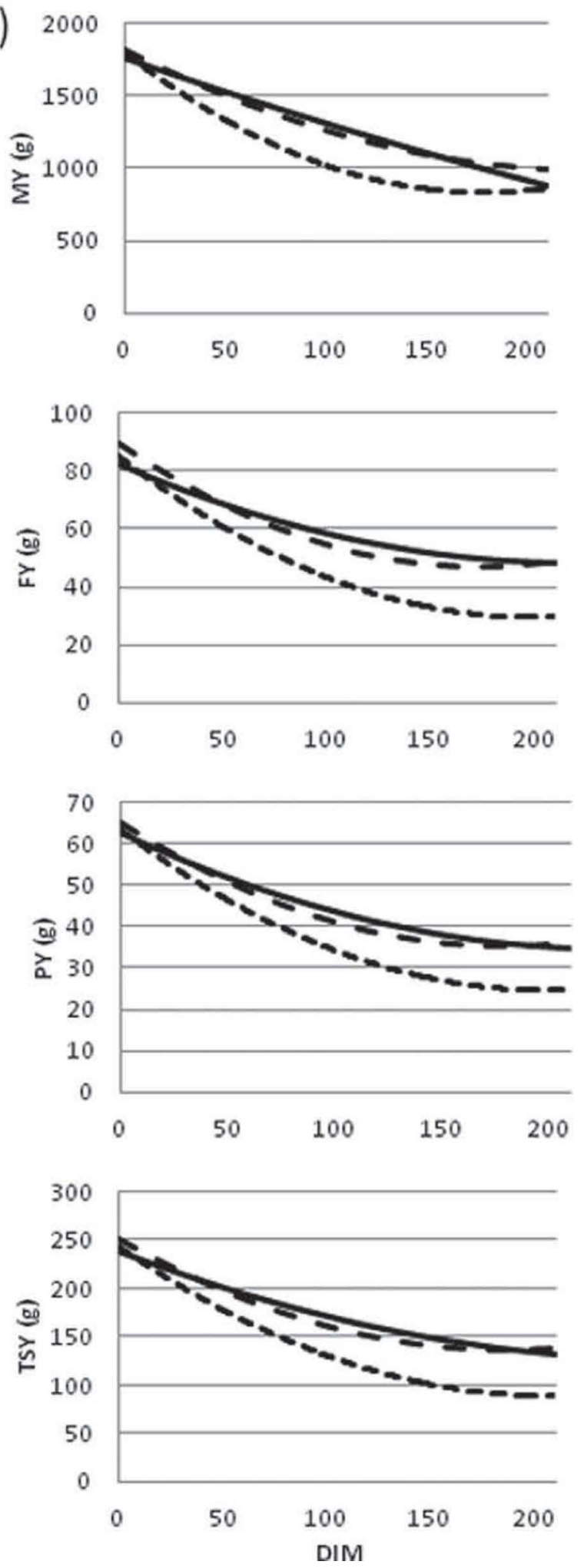

(b)
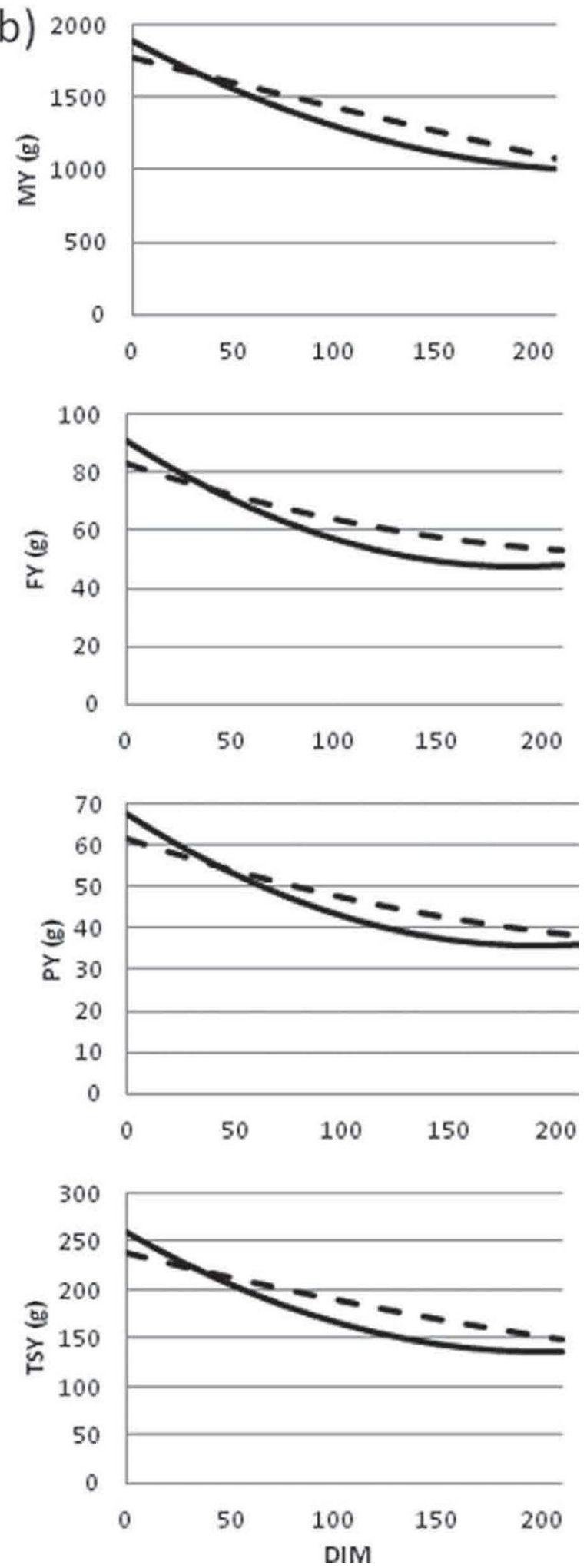

Figure 1. Average quadratic responses of $\beta$-lactoglobulin ( $B L G$; a) and $\kappa$-casein $(C S N$-3; b) genotypes for milk yield (MY), fat yield (FY), protein yield (PY), and TS yield (TSY) along the lactation. 
Table 3. Lactation time periods (in DIM) showing statistically significant differences among $\beta$-lactoglobulin $(B L G)$ and $\kappa$-casein $(C S N-3)$ genotypes

\begin{tabular}{lccc}
\hline & \multicolumn{3}{c}{ Genotype contrast } \\
\cline { 2 - 4 } Trait & $A A$ vs. $B B$ & $A A$ vs. $A B$ & $A B$ vs. $B B$ \\
\hline$B L G$ & & & \\
Milk yield & $40-125$ & NS & $40-110$ \\
Fat yield & $40-185$ & NS & $25-155$ \\
Protein yield & $40-150$ & NS & $45-80$ \\
TS yield & $35-160$ & NS & $30-115$ \\
$C S N-3$ & - & NS & - \\
Milk yield & - & $80-145$ & - \\
Fat yield & - & NS & - \\
Protein yield & - & $80-145$ & - \\
TS yield & - & & \\
\hline
\end{tabular}

then became constant at about 100 DIM. In the present study, the $B L G$ locus showed an additive effect for milk quality traits during most of lactation, including the peak, mid, and late stages (when females usually require higher dietary intake to maintain weight), and an additive effect for milk yield up to the mid-lactation stage. In turn, we detected a dominance effect only at the early stages of lactation for fat yield, which could suggest a differential (or additional) regulation mechanism for this trait. In this sense, it has been demonstrated in dairy cows that gene expression could be repressed by certain microRNA (Jabed et al., 2012), and that many loci are involved in the regulation of the concentration of $\beta$-lactoglobulin (Gambra et al., 2013). Furthermore, in goats, the number of microRNA are differentially expressed between peak and late lactation, and between peak lactation and the dry period (Ji et al., 2012; Li et al., 2012). Hence, it is possible to suggest a dominant molecular induction mechanism for the $A$ allele that could be occurring at the first stages. Reinforcing this hypothesis, a larger expression of the allele has been observed in heterozygous animals (Graml et al., 1989), possibly related through linkage disequilibrium to a polymorphism in the site for activator protein- 2 of the gene promoter (Lum et al., 1997). Finally, the insulin-signaling related genes have been shown to be highly expressed at $60 \mathrm{~d}$ in milk for lactating cows, and increased response to insulin has

Table 4. Lactation time periods (DIM) showing statistically significant additive and dominance effects for the $\beta$-lactoglobulin $(B L G)$ locus

\begin{tabular}{lcc}
\hline Trait & Additive & Dominance \\
\hline Milk yield & $40-125$ & NS \\
Fat yield & $40-185$ & $1-45$ \\
Protein yield & $40-150$ & NS \\
TS yield & $40-160$ & NS \\
\hline
\end{tabular}

been suggested for the first stages of lactation (Bionaz and Loor, 2011), which could be a plausible mechanism for the dominance effect obtained here. Of course, this latter claim stands on hypothetical ground, and further studies should be carried out to demonstrate it.

In bovines, the $C S N-3$ gene is expressed differentially during lactation (Bionaz and Loor, 2011), and the metabolic pathway of the gene involves many loci (Gambra et al., 2013). In dairy goats, the gene is overexpressed during lactation, and the expression was greater at about $100 \mathrm{~d}$ postpartum than at $310 \mathrm{~d}$ (Shi et al., 2015). In the present study, the $A B$ genotype showed better adjusted performance over most of the lactation trajectory, but the difference was statistically significant only for fat yield and TS yield between 95 and 145 DIM, consistent with the results reported by Shi et al. (2015). Furthermore, our results could also be related to those obtained in Spanish goats by Caravaca et al. (2011), who found differences in adjusted means (although not significant) between genotypes for fat yield and most of the other traits studied. As was previously discussed, differences observed in one period could be responsible for differences observed when measuring total production. Consequently, our results may suggest that differences in performance between individuals carrying different genotypes of the CSN-3 gene could be generated at about mid lactation.

\section{CONCLUSIONS}

The analysis of test-day records using a longitudinal approach showed a differential effect of polymorphisms in the $C S N-3$ and $B L G$ genes over various stages of lactation for milk yield and milk quality traits in dairy goats. The effect of the $C S N$-3 marker was significantly different for fat yield and TS yield at mid-lactation, with greater performances for the heterozygote genotype. The study also detected additive effects in the $B L G$ locus for all traits during most of lactation, but we observed a dominance effect only in early stages for fat yield. For this gene, allele A had a favorable genetic effect along the entire lactation for milk yield and milk quality traits.

\section{ACKNOWLEDGMENTS}

We thank the Goat and Sheep Breeders Association of Antioquia (Asocabra) for providing the phenotypic data, and the reviewers of the manuscript who, with their comments, contributed significantly to improving the communication of our research. This research was supported in Colombia by the Project "Estrategias para la sostenibilidad grupo GaMMA 2016" Universi- 
dad de Antioquia (UdeA), Ministerio de Agricultura y Desarrollo Rural de Colombia (MADR), Departamento Administrativo de Ciencia, Tecnología e Innovación (Colciencias, grants 528/2011 and 497/2009). In Argentina, it was supported by Consejo Nacional de Investigaciones Científicas y Técnicas (Cdad. Atma. Buenos Aires), Universidad de Buenos Aires (Cdad. Atma. Buenos Aires), and Universidad Nacional de La Plata (La Plata).

\section{REFERENCES}

Ballester, M., A. Sánchez, and J. M. Folch. 2005. Polymorphisms in the goat beta-lactoglobulin gene. J. Dairy Res. 72:379-384.

Banos, G., and M. P. Coffey. 2010. Genetic association between body energy measured throughout lactation and fertility in dairy cattle. Animal 4:189-199.

Banos, G., J. A. Woolliams, B. W. Woodward, A. B. Forbes, and M. P. Coffey. 2008. Impact of single nucleotide polymorphisms in leptin, leptin receptor, growth hormone receptor, and diacylglycerol acyltransferase (DGAT1) gene loci on milk production, feed, and body energy traits of UK dairy cows. J. Dairy Sci. 91:3190-3200.

Berget, I., H. Martens, A. Kohler, S. K. Sjurseth, N. K. Afseth, B. Narum, T. Adnøy, and S. Lien. 2010. Caprine CSN1S1 haplotype effect on gene expression and milk composition measured by Fourier transform infrared spectroscopy. J. Dairy Sci. 93:4340-4350.

Bionaz, M., and J. J. Loor. 2007. Identification of reference genes for quantitative real-time PCR in the bovine mammary gland during the lactation cycle. Physiol. Genomics 29:312-319.

Bionaz, M., and J. J. Loor. 2011. Gene networks driving bovine mammary protein synthesis during the lactation cycle. Bioinform. Biol. Insights 5:83-98.

Boettcher, P. J., A. Caroli, A. Stella, S. Chessa, E. Budelli, F. Canavesi, S. Ghiroldi, and G. Pagnacco. 2004. Effects of casein haplotypes on milk production traits in Italian Holstein and Brown Swiss cattle. J. Dairy Sci. 87:4311-4317.

Calvo, S. J., M. I. Gonzáles, P. A. Ángel, M. F. Cerón-Muñoz, and H. Cardona-Cadavid. 2012. Genetic evaluation of the goat population of Antioquia, using microsatellite markers. Livest. Res. Rural Dev. 24:82.

Calvo Cardona, S. J., J. D. Corrales Álvarez, J. L. Rocha Sarmento, L. G. González Herrera, and H. Cardona Cadavid. 2015. Association of SNPs in the genes for $\kappa$-casein and $\beta$-lactoglobulin with lactation curves in dairy goats. Pesquisa Agropecu. Bras. 50:224-232. (in Portuguese).

Caravaca, F., J. L. Ares, J. Carrizosa, B. Urrutia, F. Baena, J. Jordana, B. Badaoui, A. Sànchez, A. Angiolillo, M. Amills, and J. M. Serradilla. 2011. Effects of a s1-casein (CSN1S1) and k-casein (CSN3) genotypes on milk coagulation properties in MurcianoGranadina goats. J. Dairy Res. 78:32-37.

Caravaca, F., J. Carrizosa, B. Urrutia, F. Baena, J. Jordana, M. Amills, B. Badaoui, A. Sánchez, A. Angiolillo, and J. M. Serradilla. 2009. Short communication: Effect of $\alpha_{\mathrm{S1} 1}$-casein (CSN1S1) and $\kappa$-casein (CSN3) genotypes on milk composition in MurcianoGranadina goats. J. Dairy Sci. 92:2960-2964.

Caroli, A., O. Jann, E. Budelli, P. Bolla, S. Jager, and G. Erhardt. 2001. Genetic polymorphism of goat kappa-casein (CSN3) in different breeds and characterization at DNA level. Anim. Genet. $32: 226-230$.

Caroli, A. M., S. Chessa, and G. J. Erhardt. 2009. Invited review: milk protein polymorphisms in cattle: effect on animal breeding and human nutrition. J. Dairy Sci. 92:5335-5352.

Dagnachew, B. S., G. Thaller, S. Lien, and T. Ådnøy. 2011. Casein SNP in Norwegian goats: Additive and dominance effects on milk composition and quality. Genet. Sel. Evol. 43:31.
El Hanafy, A. A. M., M. I. Qureshi, J. Sabir, M. Mutawakil, M. M. M. Ahmed, H. El Ashmaoui, H. A. M. I. Ramadan, M. Abou-Alsoud, and M. A. Sadek. 2015. Nucleotide sequencing and DNA polymorphism studies of beta-lactoglobulin gene in native Saudi goat breeds in relation to milk yield. Czech J. Anim. Sci. 60:132-138.

Falconer, D. S., and T. F. C. Mackay. 1996. Introduction to Quantitative Genetics. Addison Wesley Longman Limited, Harlow Essex, UK.

Gambra, R., F. Peñagaricano, J. Kropp, K. Khateeb, K. A. Weigel, J. Lucey, and H. Khatib. 2013. Genomic architecture of bovine א-casein and $\beta$-lactoglobulin. J. Dairy Sci. 96:5333-5343.

Graml, R., G. Weiss, J. Buchberger, and F. Pirchner. 1989. Different rates of synthesis of whey protein and casein by alleles of the $\beta$-lactoglobulin and as1-casein locus in cattle. Genet. Sel. Evol. 21:547-554.

Hedeker, D., and R. D. Gibbons. 2006. Longitudinal Data Analysis. Wiley, Hoboken, NJ

Jabed, A., S. Wagner, J. McCracken, D. N. Wells, and G. Laible. 2012. Targeted microRNA expression in dairy cattle directs production of $\beta$-lactoglobulin-free, high-casein milk. Proc. Natl. Acad. Sci. USA 109:16811-16816.

Ji, Z., G. Wang, Z. Xie, J. Wang, C. Zhang, F. Dong, and C. Chen. 2012. Identification of novel and differentially expressed MicroRNAs of dairy goat mammary gland tissues using solexa sequencing and bioinformatics. PLoS ONE 7:e49463.

Kenward, M. G., and J. H. Roger. 1997. Small sample inference for fixed effects from restricted maximum likelihood. Biometrics 53:983-997.

Kučerová, J., A. Matějíček, O. M. Jandurová, P. Sørensen, E. Němcová, M. Štípková, T. Kott, J. Bouška, and J. Frelich. 2006. Milk protein genes CSN1S1, CSN2, CSN3, LGB and their relation to genetic values of milk production parameters in Czech Fleckvieh. Czech J. Anim. Sci. 51:241-247.

Kumar, A., P. K. Rout, A. Mandal, and R. Roy. 2009. Kappa-casein gene polymorphism in Indian goats. Indian J. Biotechnol. 8:214217.

Kumar, A., P. K. Rout, and R. Roy. 2006. Polymorphism of betalactoglobulin gene in Indian goats and its effect on milk yield. J. Appl. Genet. 47:49-53.

Li, Z., X. Lan, W. Guo, J. Sun, Y. Huang, J. Wang, T. Huang, C. Lei X. Fang, and H. Chen. 2012. Comparative transcriptome profiling of dairy goat microRNAs from dry period and peak lactation mammary gland tissues. PLoS ONE 7:e52388.

Lum, L. S., P. Dovc, and J. F. Medrano. 1997. Polymorphisms of bovine beta-lactoglobulin promoter and differences in the binding affinity of activator protein-2 transcription factor. J. Dairy Sci. 80:1389-1397.

Martin, P., M. Szymanowska, L. Zwierzchowski, and C. Leroux. 2002. The impact of genetic polymorphisms on the protein composition of ruminant milks. Reprod. Nutr. Dev. 42:433-459.

Miller, S. A., D. D. Dykes, and H. F. Polesky. 1988. A simple salting out procedure for extracting DNA from human nucleated cell. Nucleic Acids Res. 16:1215.

Moioli, B., F. Pilla, and C. Tripaldi. 1998. Detection of milk protein genetic polymorphisms in order to improve dairy traits in sheep and goats: A review. Small Rumin. Res. 27:185-195.

Pauciullo, A., G. Cosenza, R. Steri, A. Coletta, L. Jemma, M. Feligini, D. Di Berardino, N. P. P. Macciotta, and L. Ramunno. 2012. An association analysis between OXT genotype and milk yield and flow in Italian Mediterranean river buffalo. J. Dairy Res. 79:150-156.

Prinzenberg, E.-M., K. Gutscher, S. Chessa, A. Caroli, and G. Erhardt. 2005. Caprine kappa-casein (CSN3) polymorphism: New developments in molecular knowledge. J. Dairy Sci. 88:1490-1498.

Pritchard, J. K., M. Stephens, and P. Donnelly. 2000. Inference of population structure using multilocus genotype data. Genetics 155:945-959.

Rogberg-Muñoz, A., R. J. C. Cantet, M. E. Fernández, J. P. Lirón, A. Prando, A. N. Birchmeier, M. V. Ripoli, and G. Giovambattista. 
2013. Longitudinal analysis of the effects of IGF1-SnaBI genotypes on the growth curve of Angus bull calves. Livest. Sci. 154:55-59.

Sardina, M. T., A. J. M. Rosa, R. Davoli, S. Braglia, and B. Portolano. 2012. Polymorphisms of beta-lactoglobulin promoter region in three Sicilian goat breeds. Mol. Biol. Rep. 39:3203-3210.

Schaeffer, L. R. 2004. Application of random regression models in animal breeding. Livest. Prod. Sci. 86:35-45.

Shi, H., J. Zhu, J. Luo, W. Cao, H. Shi, D. Yao, J. Li, Y. Sun, H. Xu, K. Yu, and J. J. Loor. 2015. Genes regulating lipid and protein metabolism are highly expressed in mammary gland of lactating dairy goats. Funct. Integr. Genomics 15:309-321.

Strucken, E. M., R. H. Bortfeldt, D. J. de Koning, and G. A. Brockmann. 2012a. Genome-wide associations for investigating timedependent genetic effects for milk production traits in dairy cattle. Anim. Genet. 43:375-382.
Strucken, E. M., R. H. Bortfeldt, J. Tetens, G. Thaller, and G. A. Brockmann. 2012b. Genetic effects and correlations between production and fertility traits and their dependency on the lactationstage in Holstein Friesians. BMC Genet. 13:108.

Szyda, J., J. Komisarek, and I. Antkowiak. 2014. Modelling effects of candidate genes on complex traits as variables over time. Anim. Genet. 45:322-328.

Vacca, G. M., M. L. Dettori, G. Piras, F. Manca, P. Paschino, and M. Pazzola. 2014. Goat casein genotypes are associated with milk production traits in the Sarda breed. Anim. Genet. 45:723-731.

Yahyaoui, M. H., A. Angiolillo, F. Pilla, A. Sanchez, and J. M. Folch. 2003. Characterization and genotyping of the caprine kappa-casein variants. J. Dairy Sci. 86:2715-2720. 